\title{
13 The Arctic as a food-producing region
}

\author{
David Natcher, Ingrid Kvalvik, Ólafur Reykdal, \\ Kristin Hansen, Florent Govaerts, Silje Elde, \\ Bjørg Helen Nøstvold, Rune Rødbotten, \\ Sigridur Dalmannsdottir, Hilde Halland, \\ Eivind Uleberg, Jón Árnason, \\ Páll Gunnar Pálsson, Rakel \\ Halldórsdóttir, Óli Pór Hilmarsson, \\ Gunnar Pórðarson, \& Póra Valsdóttir
}

\section{Introduction}

In 2016, the Sustainable Development Working Group (SDWG) endorsed The Arctic as a Food Producing Region research project. Involving research teams from Iceland, Norway, Canada, Greenland, and Russia, the objective of the project was to assess the potential for increased production and added value of foods originating from the Arctic, with the overarching aim of improving food security, while enhancing the social and economic conditions of Arctic communities. Although the Arctic was recognised as an important foodproducing region, there was a shared sense that the Arctic was not meeting its full potential, either in terms of satisfying local food needs or for maximising its domestic or international export potential. Yet beyond speculation, much of which was informed by individual or anecdotal experience, there was little understanding of the current production capacities of Arctic food sectors or where opportunities may lie for sustainable growth. The aim of the project was, therefore, threefold: (1) complete an inventory of the current levels of Arctic food production in terms of products, volumes, revenues; (2) identify the constraints and opportunities for increased production value-added opportunities; and (3) identify potential pathways and new value chains for expanding Arctic food production and distribution opportunities.

We conceptualised the Arctic food systems in terms of primary, secondary, and tertiary production. Primary food-producing industries include fishing/aquaculture, herding, and agricultural production of raw material, including harvesting, milking, and livestock production before slaughter. In this case, the original character of the product is not changed. Secondary processing includes slaughtering, processing, packing, and transport of a product/raw material from primary production. This includes adding some 
conservatives (salt and sugar), drying, freezing, etc., to obtain a more valueadded consumer-ready product. Tertiary production involves significant changes being made to the product, by adding other ingredients for consumer readiness.

Each country lead selected a number of products/species and food producers in their respective countries to be considered, highlighting the principal value chain characteristics for their regions. While some latitude was exercised in each study region, the research was guided by a common set of questions: What is the status and potential for various food production opportunities in the Arctic? What are the added values of these products when marketed by their special qualities and unique origin? What conditions are important to the further development of the Arctic as a foodproducing region?

In this chapter, we provide a summary of food production in three regions of the Arctic. These include: (1) the entirety of Iceland; (2) Norway's three northernmost counties - Nordland, Troms, and Finnmark; and (3) northern Canada, including Yukon, Northwest Territories, Nunavut, Nunavik, and Labrador. In presenting these findings, it is important to acknowledge that we compiled national-level data on commercial food production only. Food production in and for Indigenous communities was emphasised in the areas/ countries where this was relevant but did not include subsistence or food production at the household level. Also not captured are the cultural values that Indigenous peoples assign to many of the foods that have both commercial and subsistence value. For example, while Norway's national statistics capture the economic contribution of the reindeer industry, statistics alone fall short of measuring the cultural significance of reindeer to the Saami. Similarly, export data for seals were compiled for northern Canada, including the volumes and revenues garnered from the export of meat, pelts and oils. These data in no way capture the cultural importance of harvesting, sharing, and consuming seal meat by Inuit in northern Canada. Despite this gap, the commercial results we have compiled clearly demonstrate the significant contribution that commercial food production is making to the Arctic economy, and also shows the enormous untapped potential for Arctic food production to contribute to the economic and social well-being of Arctic communities.

\section{A summary of the Arctic commercial food production}

\section{Fish and aquatic food resources}

\section{Iceland}

The export of fish and fish products are by far the most important export items from Iceland and contribute significantly to the Icelandic economy. Fish products are exported from Iceland to more than 90 countries, with the 
EU, United States, and Nigeria markets having the most commercial value. Cod, in particular, is the most important export species. The total cod catch in 2016 was 264154 tons, of which 70,000 tons $(26.5 \%)$ were caught by small vessels. In 2016, 669 tons of lumpfish caviar, 731 tons of salted lumpfish roes, and 2,700 tons frozen lumpfish blocks were exported from Iceland, worth an estimated 2,084 million ISK. A number of Arctic char farming operations are situated at different locations around Iceland. All operations are landbased and use water that, according to EU's water framework, is classified as being of unique quality extracted from springs, boreholes, and wells.

\section{Northern Norway}

From 2012 to 2016, Norway exported fish products worth 339,207,335,000 Norwegian krone (NOK). Norway's biggest market for fish products was Poland, which imported a value of 32,449,669,000 NOK in the same period. Other notable importing countries include France, Denmark, the United Kingdom, Russia, Sweden, Japan, the Netherlands, Spain, Germany, China, the United States, Portugal, and Italy, who together imported over 10 billion NOK, which accounted for $78 \%$ of all Norway fish exports from 2012 to 2016. The fish export value in Norway increased from 50.8 billion NOK in 2012 to 89.2 billion NOK in 2016, demonstrating an annual percentage increase of $8.8 \%$ in $2013,11.5 \%$ in $2014,7.3 \%$ in 2015 , and $23.9 \%$ in 2016. Over this period, the value of fish exports from Norway increased by $75.6 \%$. Only a small amount of the Norwegian seafood goes to domestic consumption. In fact, it is estimated that $95 \%$ of the fishery and aquaculture products are exported to 140 other countries. The most important species in terms of export volume include salmon, trout, cod, mackerel, herring, and saithe.

\section{Northern Canada}

Marine products accounted for $89 \%$ (3,470,745 tons) of northern Canada's total food export. Since 1988, approximately 3,470,745 tons of fish and aquatic products were exported from the Canadian north, adding more than $\$ 18$ billion, or approximately $\$ 600$ million per year, to the Canadian economy. The major commercial fisheries in northern Canadian are turbot, shrimp (northern and striped), and Arctic char, that are shipped fresh and frozen as a whole and as fillets. Other commercial products include dried fish, fish meal, molluscs, live fish, and other aquatic invertebrates. Among 133 export destinations, the United States, China, Japan, Denmark, and Russia are the leading importers of northern Canadian seafood. The revenue generated from commercial fisheries has increased slightly in recent years, from $\$ 709$ million in 2010 to $\$ 798$ million in 2019. The fish harvest in the Canadian Arctic underwent substantial changes from 1950 to 2018. From 1950 to 1960, the total harvest increased from 1,924.7 tons/year to 3,286.9 tons/year. A decline from 1960 until the early 1990s to 850 tons/year 
brought the harvest down to almost one third of the peak harvest in the 1960s. From 1994 to 2018, a slight increase led to a fish catch of 993.6 tons in 2018. In addition to fisheries, Canada has exported (2005 and 2014) more than $\$ 66.6$ million worth of seal products (pelts, meat, and oils) to 48 countries.

\section{Meat production}

\section{Iceland}

There are over 3,000 sheep farms in Iceland. These farms tend to be small and family owned. The sheep farming is as old as the human settlement of Iceland. Iceland is very well suited for sheep farming with plentiful grasslands and highland pastures. Lambs graze in the highlands until slaughtered in the autumn. The grazing areas are comprised of native vegetation, which enhances the quality and reputation of Iceland's lamb industry.

There are ten slaughterhouses for sheep in Iceland. During the 2017 slaughter season, 560,500 lambs were slaughtered. The average carcass weight was $16.5 \mathrm{~kg}$ and total production was 9,200 tons of lamb meat (carcasses). The value was 6,200 million ISK for lamb meat sold at the domestic market. The volume of exported lamb and sheep meat was 4,100 tons. The challenges for sheep farmers are low income and the need for off-farm employment. The slaughterhouse industry has a strong position on the market and needs a considerable share of the market value. The sheep farming industry also faces competition from other more profitable meat sectors. Beyond meat production, sheep farming includes secondary production. For example, skyr production has been a part of the Icelandic cuisine since settlement. The industrialisation of skyr started in the 1930s. Gradually domestic production of skyr decreased and by 2010 only a few farms were reported as skyr producers. In the last few years several farms have started to produce skyr according to the traditional methods that have been accompanied in growth in domestic sales. Skyr has in the past been sold mainly within Iceland but in recent years has been increasing in international exports. About 4,500 tons are produced annually. A total volume of about 1,300 tons are exported for a value of about 500 million ISK. The remaining 3,200 tons are sold on the domestic market.

\section{Northern Norway}

The largest agricultural production systems in Northern Norway are based on meat production. Abundant high-quality grazing areas are an important reason for quality production, but also benefits from substantial barn capacity. In the primary production, there are 1,312 producers of cattle (mainly dairy farmers), 1,608 sheep producers, 115 pork producers, and approximately 30 dairy goat farmers. The total primary production was 186,462 
sheep, 28,061 cattle, and 103,600 pigs slaughtered in 2016. In that same year, there were approximately 1,000 employees in the secondary and tertiary industry in northern Norway. The meat products are sold locally, regionally, and nationally. The industry is characterised of high level of processing. There are possibilities for increased meat production in the north, both by utilising the total potential in the outfield grazing fields for increased primary production and by increasing the value-added by producing local specialty products. Northern Norway also produces dairy cattle, sheep, and goat. This industry is more less dominated by large cooperatives owned by the farmers, including TINE (dairy) and Nortura (meat), which are supplied by roughly 500 local producers.

The reindeer industry in Norway is closely connected to the Saami-culture and heritage. Only persons of Saami descent can be owners of reindeer, a right protected by law. In 2017, 3,233 persons were registered as reindeer owners in Norway. However, slaughtering and processing of the animal products is open to the qualified general public. The majority of reindeer are found in Finnmark (75\%), while Troms and Nordland have approximately $6 \%$ and Trønderlag has $14 \%$. The reindeer are semi-domesticated, which means they roam freely, where they consume grass during summer and lichen during winter.

\section{Northern Canada}

The value of live animals and animal products exported from northern Canadian has increased steadily over the last 30 years. During the 1990s, the average revenue from sales was roughly $\$ 858,814$ CAD per year. However, by 2000 , annual sales increased to $\$ 2.5$ million CAD, or an increase $300 \%$. Overseas exports fluctuated from 2000 to 2017, with the highest values being \$3.5 million in 2003 and \$4 million in 2011.

The western Canadian Arctic area near Sachs Harbor and Ulukhaktok is known for its large-scale commercial harvest of muskoxen. Usable parts from a muskox include meat, hide, wool (Qiviut), and horns. Northern communities export these items to markets in southern Canada. In addition to hunting for subsistence and marketing purposes, guided sport hunting-and-outfitting based tourism connected to muskoxen provides a source of food and income for northern communities. In the Northwest Territories (NWT), the Inuvialuit Regional Corporation helps Sachs Harbour residents hold a community muskox hunt on Banks Island. The muskox population on the island fluctuates between 80,000 and 120,000 animals. At present, the community harvests a few hundred muskoxen annually (roughly $4 \%$ of the total estimated population). On average, the hunt brings $\$ 70,000$ worth of wages to Sachs Harbour and employed more than 20 community members in meat processing and an additional 30-35 hunters involves in the actual harvest (Ryan, 2006).

Although caribou hunting in northern Canada supports household subsistence and inter-settlement trade, the feasibility of commercial hunts is 
limited. As supplies from wild harvests are intermittent, this influences the commercialisation of caribou meat or any other types of sales of caribou in southern markets. The uncertainty of supply makes buyers from outside Canada hesitant to enter into contracts with northern producers, reducing the viability and commercial value of the caribou harvest.

\section{Agricultural production}

\section{Iceland}

Geothermal energy for heating and electricity produced by hydroelectric power stations for illumination are the basis of vegetable production in greenhouses in Iceland. Most of the greenhouses are located in clusters where geothermal energy is available. Several greenhouses operate through long winters by using electrical illumination. The vegetables typically grown yearround in greenhouses include tomatoes, cucumbers, bell pepper, and lettuce, but in some cases also includes spinach, cabbage, kale, and herbs. Some greenhouses have successfully grown strawberries but have been challenged financially when competing with the lower imported prices. Agricultural products are marketed primarily for domestic markets. The greenhouse production of cucumbers, tomatoes, and bell pepper was 3,500 tons in 2016. The total value of greenhouse and out-door vegetable production in Iceland was 3,800 million ISK 2016. The value of greenhouse products is a considerable part of this, estimated to be about 1,500 million ISK. The number of employees in vegetable production was roughly 237 and for related services 107 employees were involved (outdoor production included). The greenhouse vegetable production in Iceland meets only a part of the domestic demand. The market share for domestic tomatoes and cucumbers is the highest (70-90\%) but lowest for lettuce and bell pepper (about 10\%). The import of vegetables is therefore considerable. Vegetable production could be increased considerably, however there is import competition. Barley production in the country is 10,000 to 16,000 tons per year. Only about $2 \%$ of the barley is used for food, but this proportion could be increased.

\section{Northern Norway}

The agricultural production in northern Norway is the northernmost active agricultural system in the world. It is only possible because of the warm air carried by the North-Atlantic current and because of the latitudinal placement of the region; growing conditions that are characterised by short growing season and 24-hour day daylight in mid-summer. The main horticultural production is potatoes that are grown on about 460 hectares. Vegetables and berries are grown on about 65 hectares with about equal distribution in Troms and Nordland counties. Key strengths for horticultural production in Northern Norway are the natural growing conditions with cool summers 
and long days. These conditions imply little problems with pests and diseases and require low use of pesticides and herbicides. There are also indications of specific quality attributes of horticultural products produced under these growing conditions. It has been documented in several horticultural products grown in Northern Norway that the low temperature, in combination with 24-hour light and longer photosynthetic activity, causes more crispy and juicy products with sweeter taste compared to the same product produced further south. It is usually not a result of the increased amount of sugars, but rather less production of different kind of bitter-tasting substances. Several food producers in Northern Norway are using these particular biological attributes together with the product origin, for marketing products with 'Arctic quality.' This is used in the successful marketing of a locally produced potato variety gulløye, as "the potato of the midnight sun."

\section{Northern Canada}

From 1988 to 2017, 3641 tons of roots, tubers, cucumbers, beans, chickpeas and mushrooms were harvested in the Canadian Arctic and exported (mostly frozen) to countries around the world. The highest volume was in peas, with 492 tons exported to China in 2006, and potatoes, with 275 tons $(\$ 107,621)$ exported to Russia in 2014. During that same period, blueberries, cranberries, bilberries, raspberries, and blackberries accounted for 3,377 tons in export. The Netherlands and other European Union countries were the major markets for fruit and nut products from northern Canada. From 1988 to 2017, the total weight of oil seeds, oleaginous fruits, straw, and fodder exported from northern Canada reached 1,202 tons $(\$ 1,689,154)$ and contributed $13 \%$ to the total weight of farm exports. Other farm products including live trees, teas, cereals, malts, starches, resins, and vegetable saps, were also exported with a weight of 964 tons $(\$ 1,346,561)$. Unlike the large commercial farms in the Canadian prairies, agricultural production in the Canadian north is conducted small-scale farms, community gardens, and greenhouses. The 2016 Census of Agriculture indicated that there were 142 farms operating in Yukon, encompassing a total farm area of 10,330 hectares, with 6,801 ha involved in pasture and the production of crops. The number of farms operating in Yukon has fluctuated since the 2001 Census of Agriculture, from a high of 170 (2001) to a low of 136 (2006), though the total area in production has not changed as notably.

\section{Discussion}

The objective of the Arctic as a Food Producing Region project was to identify new food production opportunities that could lead to sustainable economic development for Arctic communities. Preliminary results show that within the Arctic region there are considerable opportunities for commercial food production, both for export and for meeting local food needs. 
Food industries are producing large volumes of food commodities that are culturally compatible with Indigenous/local food preferences and also have high export value.

There are, however, large variations in actual and potential production and harvesting volumes, both between Artic Nations, species, and product groups. The volume variations at a national level can, for instance, be seen in the export statistics. These differences will have a large effect on product development and marketing strategies chosen by producers as a whole. Whereas variations exist in production levels, critical infrastructure, marketing access, lack of available raw material, and skilled workforce, and environmental issues are some of the main challenges shared by all. Arctic food industries also experience production or harvesting limitations, due to national regulations (for example, quotas, health, and safety legislations) or natural conditions of the Arctic (for example, climate, availability of food sources, and resource availability). Second, high transport costs and export tariffs on high-value food products, affect the profitability of food-producing companies, for example, contributing to less processing of seafood within the Norwegian or Canadian borders. Third, there is a general shortage of skilled labor in many rural and remote areas. Since food harvesting and/or production in most instances are located in districts/regions with low population density, acquiring knowledgeable and flexible employees can be a constraint to industry development. For example, the population in northern Iceland has been declining over the last few decades and this could develop to a critical constraint to industry growth. Iceland, except for the capital area, is sparsely populated, with changing demographics impacting regional innovation capacity. Qualified human recourses are important to allow for industry innovations that will be necessary to capitalise on existing and emerging markets. Lacking the necessary labor and human resource capacities may then limit investment interest that will be the key to stabilising the populations of remote regions.

The Arctic climate poses obvious constraints to the development of food industries, particularly in the context of agricultural expansion and diversification. This includes hampering the adoption of new food-producing technologies that are more readily available in southern markets. For example, in southern Canada, the largest algae cultivation systems to date use open pond systems. These autotrophic systems, however, have limited applicability in Canada's northern climate. Given the high capital and operating costs of closed photobioreactor systems, most analysts are skeptical that economically sustainable algae cultivation can take place in northern Canada. Factors limiting algae biomass production in northern Canada include limited solar irradiance, high capital costs, high energy and operating costs, few opportunities for colocation with symbiotic industry partners (Pankratz, Oyedun, Zhang, \& Kumar, 2017).

Legislation at various levels of government also prohibits or severely restricts local food production, particularly for export markets. The 
requirement to meet federal food safety and inspection has also restricted the commercial development of these foods for export, which in turn, has limited entrepreneurial development. Other country-specific legislation can further impede industry development. For example, in Canada a federally supported food program (Nutrition North Canada) subsidises the transportation costs for selected foods shipped from the south to northern communities. The objective of the program is to help make healthy foods more affordable and accessible to northern communities. On average, the program provides an annual subsidy of $\$ 65$ million, nearly half of which subsidises the transport of meat, fruits, and vegetables. As of 2018, 121 northern communities were eligible for subsidised food rates. While well-intentioned, the subsidy program has in some cases caused economic disincentives for local food producers, as the subsidised costs of imported foods are often lower than actual costs of food produced in the north. Adding further challenges to local food production in northern Canada are the Comprehensive Land Claims (CLC). The settlement of Comprehensive Land Claims (CLC) recognises Indigenous ownership of over $600,000 \mathrm{~km}^{2}$ of land, protection of traditional ways of life, confers exclusive and preferential harvesting rights, and provides for Indigenous participation in land and resource management decisions. CLC have the potential to facilitate entitlement and access to food as they contain specific provisions that protect Indigenous hunting, harvesting, and fishing rights. While the settlement of CLC has in many ways empowered Indigenous peoples in Canada, the specific provisions found in these agreements have also created barriers to the development of food-related industries. While the provisions vary from one CLC to another, most contain explicit language that prohibits the commercial sale of traditional foods. The only exception being the Nunavut Land Claims Settlement that was signed in 1993.

\section{Opportunities}

Notwithstanding the challenges noted above, there are opportunities for increased food production in the Arctic. While the Arctic climate is a constraint to some areas of food production, new opportunities may also arise from global warming, especially within land-based production. Agriculture in Arctic regions is considered marginal, due to short growing seasons with low growth temperatures. The forecasted increase in temperature due to global warming is predicted to be greater in the Arctic than the global average. As the growing season is being prolonged, it creates opportunities for new and or marginally productive agricultural species, especially annual species and even barley cultivation.

Opportunities for increasing food production and adding value, improving product quality, and increasing food tourism and local markets also exist. This has been the case in northern Canada where the production of prepared or value-added foods has been steadily increasing since 1990s. 
Since 2000, the export volume of prepared foods has increased by approximately 18,000 tons per year, or an increase of $384 \%$. These exports consist mainly of value-added fisheries products (for example, farmed char), but also includes agricultural products (berries, teas, and beverages) that are contributing to local economies and food security of the region.

Identifying special chemical attributes within raw materials and using this for marketing or as extractions of valuable compounds used within the industry may also be an opportunity for growth. Other food innovations could include the introduction of full utilisation methods and new production methods, for example using waste products from the seafood to produce medicine or fabrics or seaweed production as both a food source and for $\mathrm{CO}_{2}$ sequestration. Iceland has a variety of biological resources available for sustainable and responsible utilisation, some of which are underutilised. The major underutilised resources include side streams, such as those found in the marine and agricultural industries. However, data on these resources are sparse, resulting in ineffective decision-making and inefficiencies in technological innovations.

Iceland, Norway, and Canada each have the advantages of adding value to the products by further processing and product development or identifying the local value by historic background or Arctic quality for increasingly growing consumer market. Iceland and Norway are already identifying special chemical attributes within the raw material produced in the Arctic climate and using this for marketing or as extractions of valuable compounds used within the industry. For these reasons, some of main opportunities for increased food production and value-adding revolves around niche products and storytelling, better use of surplus biomasses, improving product quality, and increasing food tourism and local markets.

There are also opportunities for increased food production in the Arctic given the demand for high-quality foods, which are culturally compatible, and sustainably produced. Local niche products are being developed for specialised markets. New opportunities might include domestic food production in farms and villages to meet local needs while reducing carbon footprint. These are proving to be an interest to tourists who are visiting northern regions and who are receptive to local foods and food-related experiences. The continued growth of the tourist industry could become important for the food-related economy of the northern regions. The increasing number of tourists also increases the demand for food. To satisfy this demand, local food production will need to increase production or risk an even greater reliance on food imports. The tourism industry provides an opportunity for food producers to increase production and develop new products. Regional products are of particular interest to tourists and also help to increase sustainability and support local food producers and spinoff industries.

Food originating from the Arctic may also have a marketing advantage. Consumers generally prefer food that is healthy, with good taste, and 
produced in a sustainable manner, and increasingly they prefer food with a unique story. Food from the Arctic may score high on all these characteristics. There are significant opportunities for developing high-value niche "Arctic products" for tourist markets and other selected regional and national markets. Consumer preference studies conducted in Norway (this volume) and Canada (Yang et al., 2020) indicate that consumers feel the consumption of Arctic foods allow them to experience Indigenous cultures and tradition, while supporting Indigenous communities economically. Compared to other places of origin, Canadian and Norwegian consumers place higher value on the features of Arctic origin, and would choose to purchase wild-caught fish by remote/Indigenous producers over other southern-based alternatives. Consumers have also shown support for new certification standards for Arctic sustainability and authenticity, which could be further used as a marketing advantage.

\section{Summary}

Our results indicate that within the Arctic region there are considerable opportunities for commercial food production, both for export and for meeting local food needs. Yet Arctic food industries are also challenged by a plethora of social, economic, climatic, and logistical constraints. Despite the growth in commercial food production in the Arctic, there remain a considerable number of constraints to industry development, including lack of necessary infrastructure, fragmented supply chains, limited access to a skilled workforce, absence of innovation in product development, and limited access to, and knowledge of, domestic markets and consumer interest. While these challenges are experienced unevenly across the Arctic regions, Arctic food industries, as a result, tend to be fragmented with tenuous professional connections and limited communication streams. These conditions have in part led to their general overreliance on raw food exports, imported packaged foods, bottlenecking of distribution points, and limited innovation in primary and secondary product development. These conditions, in turn, have accelerated a nutrition transition among populations characterised by an erosion of diet quality, increased consumption of ultra-processed foods.

Land-based plant production in the Arctic has not received much attention over the years, although it may be of global importance to utilise the production capacities of the northern regions. The effects of global warming have the potential to provide new opportunities for growing new crops and cultivars with a higher yield potential within a prolonged growing season. To identify the capacity for increasing plant production and agriculture in Arctic areas, it is of major importance to understand the mechanisms behind the effects of climate change on plant production and plant persistence. Screening of available genetic resources in the Arctic is important for selecting well-adapted plant material both for crop production and for 
the preservation of biodiversity. Implementing technological solutions into production systems will further increase the production potential. For the successful development of rural plant production, knowledge transfer is crucial. This can be achieved by strengthening and enlarging the R\&D network to support collaboration across national borders in the Arctic. Engaging Indigenous communities and industry stakeholders could enhance innovations in agriculture and create new markets and employment opportunities for northern communities. A better insight into the effective use of available plant genetic resources could also give social and economic advantages for the future rural population in Arctic regions. Future opportunities also lie in new and better storage methods for seasonal raw material and full utilisation of raw materials.

Icelandic Food and Biotech R \& D (Matis), has already established several food innovation centers at various locations in the country. Support from regional innovation centers has been a successful strategy for smallscale product development. The intention is to improve regional food production further and the Icelandic government is expected to increase funding for local and regional innovation in food sectors. This is important, as small-scale local and regional food producers and entrepreneurs need financial assistance in the early stages of food innovation. Norway has adopted a similar approach to stimulating innovation in the food sectors. There has been a focus on building various types of network cooperation between the local food companies. These networks are often partly funded through Innovation Norway. Most networks are geographically linked like Nordlandsmat or Vesterålsmat, but some are also focused on a specific product type like Lofotlam (sheep meat) and Arktisk kje (goat meat). These networks focus on overcoming the challenges of being a small producer in the north by achieving large-scale advantages and capitalising on economies of scale in distribution, sales, and marketing. Evaluations conducted by Innovation Norway found that industry success most often requires business objectives to be clearly defined and offer value to all parties in the value chains. In addition, it was found that success takes time and trust between the companies, especially if they see themselves as competitors, is required. Some of the more successful networks in Norway have evolved for over a decade like LofotenMat (founded in 2007) and Fjellfolket (funded in 2006). During this time governmental support has been critical for build up the local food sector in Norway and in launching the Centre of Expertise in 2002 for local food production, with a northern hub is located at Nibio in Tromsø. The target industry groups are small to medium-sized food producers whose shared goals include adding increased value to Arctic food products through innovation, skills development, and entrepreneurial training.

We believe the time is right for a pan-Arctic focus on food production and sustainable economic development. Investing in Arctic food systems transformation requires a systems-based approach to policy formulation and investment grounded on a solid foundation of interdisciplinary research 
that connects capacities and institutions across the Arctic. Likewise, achieving the food security for all Arctic peoples requires a robust research agenda that is developed and implemented in a concerted manner with consistent investment. The international experience and development discourse are much better informed by research in the Global South. The International Food Policy Research Institute (IFPRI), for example, was established in the 1970s alongside substantial investments in agricultural research and the establishment of the global, multi-hub Consultative Group on International Agriculture Research (CGIAR), with the explicit purpose of facilitating independent research that would deal with socioeconomic policies for agricultural development and to improve the understanding of national food policies to promote the adoption of innovations in food producing technologies. With the establishment of national 'hubs', a cluster-based approach to Arctic food innovation could similarly draw together Arctic food producers with governments, Arctic Indigenous communities, universities, research centers, vocational training providers, and industry associations and young people. Such a concerted focus on food production and Arctic sustainable development would prove capable of responding to global challenges and would define the Arctic's role in sustainable development locally and around the world.

\section{References}

Animalia statistikk. (n.d.) Slaktestatistikk per dyreslag. Animalia. http://statistikk. animalia.no/statistikk/

Dalmannsdottir, S., Jørgensen, M., Rapacz, M., Østrem, L., Larsen, A., Rødven, R., \& Rognli, O. A. (2017). Cold acclimation in warmer extended autumns impairs freezing tolerance of perennial ryegrass (Lolium perenne L.) And timothy (Phleum pratense L.). Physiologia Plantarum, 160, 266-281.

Johansen, T. J., Hykkerud, A. L., Uleberg, E., \& Mølmann, J.. (2018). Arktisk kvalitetEn beskrivelse av nordlige natur- og klimaforhold og virkning på egenskaper hos nordnorske matprodukter. NIBIO Rapport. http://hdl.handle.net/11250/2494675.

Landbruksdirektoratet. (n.d.). Statistikk fra søknader om produksjonstilskudd i jordbruket. Landbruksdirektoratet. https://www.landbruksdirektoratet.no/filserver/ prodrapp.htm

Lusk, J. L., \& Briggeman, B. C. (2009). Food values. American Journal of Agricultural Economics, 91(1), 184-196.

Matmerk. (2016, October 27). Lokalmatsalget vokser mest. Matmerk. https://www. matmerk.no/no/matmerk/aktuelt/lokalmatsalget-vokser-mest

NIBIO. (2020). Kompetansenettverket for lokalmat $i$ Nord. NIBIO. https://www. nibio.no/tema/mat/kompetansenettverk-for-lokalmat-i-nord

Pankratz, S., Oyedun, A. O., Zhang, X., \& Kumar, A. (2017). Algae production platforms for Canada's northern climate. Renewable and Sustainable Energy Reviews, 80, 109-120.

Pettersen, I. (2018). Mat og Industri. NIBIO. www.matogindustri.no

Proff. (2020). Proff-the Business Finder. Proff. www.proff.no 
Ryan, R. (2006). Summary of proceedings: Building a kitikmeot economic development strategy. Proceedings Report KEDC. Regional Planning Meeting.

Statistics Norway. (2018). External Economy: External Trade. Statistics Norway. https://www.ssb.no/en/utenriksokonomi?de=External+trade+

Statistics Norway. (2018). Meat Production. Statistics Norway. https://www.ssb.no/ statbank/list/slakt?rxid=2c9310c4-9a42-4bf9-ae33-94ebde71e54a

Stiberg-Jamt, R., Brastad, B., Flatnes, A., Hauge, E., Tobro, M.,\& Geschwandtnerova, V. (2018). Evaluering av Bedriftsnettverks-tjenesten til innovasjon Norge. Oxford Research.

Yang, Y., Hobbs, J., \& Natcher, D. C. (2020). The Arctic as a food producing region: Consumer perceptions and market segments. Canadian Journal of Agricultural Economics. doi: https://doi.org/10.1111/cjag.12255. 